Revista Iberoamericana, Vol. LXXVI, Núm. 232-233, Julio-Diciembre 2010, 821-836

\title{
MODERNIDAD Y ABYECCIÓN EN LA NUEVA NARRATIVA VENEZOLANA
}

\author{
POR \\ Miguel Gomes \\ The University of Connecticut-Storrs
}

\section{UN CICLO NARRATIVO}

La profunda crisis de la Venezuela de fines del siglo xx y principios del xxi se vincula en muchos sentidos a la ambivalente trayectoria de lo moderno en el país. La modernización venezolana suele manifestarse de manera particularmente contradictoria desde que en la década de 1910 Juan Vicente Gómez, dictador engendrado por el caudillismo semifeudal decimonónico, “patriarca primitivo” (Campos 94), les abrió las puertas a las compañías petroleras estadounidenses, cuya presencia contribuyó a sustituir una economía agrícola con una centrada en la explotación de hidrocarburos, lo que pronto permitió cancelar la agobiante deuda externa anterior (McBeth 122). El brusco desarrollo promovido por una autocracia desde tantos otros puntos de vista arcaizante es afín a paradojas posteriores, como la de la incapacidad de la democracia que nació en 1958 para invertir sensatamente el enorme flujo de capitales que la industria petrolera siguió trayendo a Venezuela. Marco Cupolo, de hecho, se ha referido a la transición entre milenios como una auténtica "noche pospetrolera" por el derrumbe de la "euforia" desarrollista que hasta los ochenta había caracterizado al país (134-140). Fernando Coronil ha sugerido que tal derrumbe se relaciona con una "traición” simbólica percibida por las masas, acostumbradas a la idea de que pueblo y riqueza natural se consustanciaban gracias a la acción unificadora del estado. Ese resquebrajamiento de la imagen propia se produce al final de la década de 1980, con eventos muy específicos como la eliminación de subsidios de la gasolina propuesta por la segunda administración de Carlos Andrés Pérez que acabaría causando uno de los estallidos de violencia más memorables de la historia reciente de Venezuela, el "Caracazo" de febrero de 1989:

[La] medida destruyó la unidad del cuerpo político, propietario del cuerpo natural de la nación: violando lo que la gente consideraba como su derecho de nacimiento, se rompió un pacto moral de protección entre el estado y los ciudadanos. (376) ${ }^{1}$

1 Traduzco a lo largo de este trabajo las citas provenientes de la bibliografía secundaria. 
El tipo de desencuentros de fines del siglo xx confirma que esa conflictiva tradición persiste: aunque el ansia de cambio político que en los discursos públicos enfatiza lo "revolucionario" encaja de lleno en ideales modernos, igualmente recae en los oportunismos financieros de la democracia anterior, potenciados por la bonanza minera. A ello se suma, por una parte, un espíritu neocaudillista que rinde tributo a los padres de la patria y al líder supremo del proceso -éste ha enfatizado el paralelismo entre él y ellos-y, por otra, discursos marxistas ya entreverados, desde los años setenta, de cultura pop y, mucho antes, de ideologemas arielistas. Quien mejor ha descrito la intrincada situación es Germán Carrera Damas al observar en varios países latinoamericanos

una tendencia a buscar salidas a la desorientación ideológica mediante la adopción de las que cabría denominar "ideologías de reemplazo”, suerte de confusas alternativas ideológico-políticas validas de procedimientos que combinan el más rancio autoritarismo con la más desenfadada demagogia, y cargadas de contenidos liberales y socialistas, si bien estos últimos han sido hasta ahora más bien retóricos. (13)

El chavismo, según Carrera Damas, es la versión venezolana de esa tendencia, que se impuso desde 1998 como un "bolivarismo-militarismo” donde se aúnan arbitrariamente posiciones reformistas y revolucionarias con un salvacionismo laico que arranca de las maniobras autolegitimadoras de dictadores como Antonio Guzmán Blanco y Juan Vicente Gómez (22-27), quienes forjaron “un Bolívar ad hoc” (19). La enorme división suscitada por las proclamas del chavismo, que ha generado incluso derramamientos de sangre, con su obstinado recurso a la terminología "bélica” (882-883) y frecuente amalgama de “popularización” y “polarización” (878), ha exacerbado en muchos el estado de ánimo que la metáfora de una “noche pospetrolera” compendia.

La expresión de Cupolo intenta verbalizar lo que Raymond Williams reconocería como una estructura del sentimiento (structure of feeling), un conjunto de experiencias, valores o creencias compartidos pero tenidos por individuales debido a su carácter aún subjetivo, inconsciente. En contraste con las ideologías o las cosmovisiones, declarables en escritos teóricos, las estructuras del afecto se componen de ideas tal como se sienten y sentimientos tal como los concibe el intelecto, logrando a duras penas entrar en una argumentación puesto que constituyen vivencias no del todo interpretadas (138-135). La sensación de "noche" puede rastrearse en diversas obras literarias que parecen estar elaborando una noción más codificable y políticamente precisa. El objeto de este trabajo es describir una serie de coincidencias en varias novelas que permite entrever que la comunidad letrada esboza asociaciones y representa como factores contiguos, o fenómenos de un mismo orden, el auge del chavismo y las irresolubles contradicciones de lo moderno tal como se ha planteado en Venezuela.

No creo arriesgado, de hecho, discernir un auténtico "ciclo" narrativo que ha ido cristalizando desde la aparición en 1992 de Hugo Chávez Frías en la vida pública,

Revista Iberoamericana, Vol. LXXVI, Núms. 232-233 Julio-Diciembre 2010, $821-836$
ISSN 2154-4794 (Electrónico) 
con su participación en un abortado golpe de Estado contra un presidente elegido democráticamente -Carlos Andrés Pérez. El encarcelamiento de Chávez, su liberación y vertiginoso ascenso al poder en las elecciones de 1998, seguido de divisiones entre sus partidarios y en la opinión nacional, cuyo clímax hasta ahora ha sido la violencia de abril de 2002, donde sectores de la oposición adoptaron plenamente la lógica del chavismo y llevaron a cabo un simétrico golpe de Estado -también fallido-, ofrecen un contexto específico para importantes títulos emparentados entre sí por la plasmación neoexpresionista de las “tinieblas" espirituales del país a la llegada del nuevo milenio. Sólo quiero que amanezca (cuentos, 1999/2002) de Óscar Marcano; También el corazón es un descuido (novela, 2001) y La enfermedad (novela, 2006) deAlberto Barrera; Falsas apariencias (cuentos, 2004) de Sonia Chocrón; Pecados de la capital (cuentos, 2005) y Latidos de Caracas (novela, 2007) de Gisela Kozak; Nocturama (novela, 2006) de Ana Teresa Torres y Fractura (cuentos, 2006) de Antonio López Ortega, entre otras, son obras que podrían probarlo.

Me concentraré en las novelas de la lista anterior (También el corazón es un descuido, La enfermedad, Nocturama y Latidos de Caracas) por cuestión de espacio, aunque también de genología: los amplios panoramas sociales que debemos a Barrera, Torres y Kozak hacen más explícito el diálogo, que a propósito o no, el escritor entabla con su entorno. La difusión de dos de estos novelistas -extraordinaria en términos de autores venezolanos- $\mathrm{y}$ los premios que han recibido los tres permiten suponer asimismo que han tenido mayor oportunidad de moldear la imaginación colectiva. ${ }^{2}$ El examen detenido de los textos seleccionados precederá a una discusión de sus vínculos argumentales y retóricos que facilite la comprensión de la estructura afectiva que a mi ver comparten, vertebrada por una captación del deterioro de la nación, así como por una circunspecta crítica del autoritarismo.

\section{TAMBIÉN EL CORAZÓN ES UN DESCUIDO Y LA ENFERMEDAD}

The death [...] of a beautiful woman is, unquestionably, the most poetical topic in the world ('La muerte de una mujer hermosa es, indiscutiblemente, el tema más poético del mundo’): la célebre sentencia de Poe (105) puede situarnos en el espacio problemático que traza la primera novela de Alberto Barrera. Me refiero al del bárbaro asesinato de una mujer fea cometido por un inmigrante venezolano en Stonehill, comunidad apacible

2 La enfermedad ganó el Premio de Herralde de Novela 2006 (España) y Gallimard pronto la pondrá a circular en francés. Varias obras de Torres se han traducido y la autora cuenta con el Premio Municipal de Narrativa de Caracas (1991, 1998), el Premio de Narrativa del Consejo Nacional de la Cultura (Venezuela, 1991), el Premio Pegasus de la Corporación Mobil (1998), el Premio Anna Seghers (Berlín, 2001) y otros. La labor de Kozak también se ha premiado en Venezuela (Bienal de Narrativa Alfredo Armas Alfonso, 1997) y ha llamado la atención de varios comentaristas.

Revista Iberoamericana, Vol. LXXVI, Núms. 232-233 Julio-Diciembre 2010, 821-836 
de Ohio: “le sacó el páncreas, el hígado, el riñón izquierdo y la vesícula” (9). Eso y las aventuras rocambolescas de un reportero enviado desde Caracas para escribir acerca del juicio constituyen los puntos de partida de También el corazón es un descuido.

La imagen de la "bella muerta” ilustra con las morbosas bondades del caso el lugar que una sociedad patriarcal asigna a los sujetos que subordina (Bronfren 59); ese orbe de lo rechazado o dominado equivale, no siempre metafóricamente, a la muerte, el silencio, la incapacidad de acción en el mundo material. La ironía inicial de Barrera, hacer que un psicópata se obsesione hasta el crimen por “mujeres feas (espantosas)”, se fundamenta, por supuesto, en la inversión de un cliché: Ofelias ahogadas, descompuestas damas prerrafaelistas dadoras de poemas, tenues Marías que la epilepsia disuelve. Pero dicha inversión constituye sólo una de las muchas que organizan el discurso novelesco. No olvidemos que el amante y asesino de feas viene de Venezuela o, mejor dicho, de la ahora "República Bolivariana”, como el narrador periodista se encarga de recordárnoslo (119), y que éste es "un país de misses”, como también lo destaca (126): si el militarismo chavista “da grima” por más que se adorne con un vocabulario heroico (119), la apolíneamente codificada adoración de lo bello asimismo degenera en el deseo de fealdad, incluso llevado a lo tangible y dionisíacamente orgiástico -con un desmembramiento, después de todo, se manifiesta la plenitud extática a la que llega el "Carnicero de Stonehill”.

Los dobleces lúdicos del libro de Barrera no se agotan en el horizonte político. Piénsese en la curiosa relación especular que se establece entre asesino y periodista. Para obtener detalles del suceso, éste acepta hacerse pasar por hermano de aquél. El vínculo de sangre, al principio mero simulacro creado por el abogado defensor en su intento de suscitar una telenovela judicial del mismo calibre que la de O. J. Simpson, no tarda en arraigar en el ánimo del narrador, que hasta se las arregla para pasar una noche en el lecho donde se cometió el crimen. Lo cierto es que el periodista acaba en cierta forma convertido en el criminal que debería ser objeto de repulsión. Héroe y antihéroe intercambian o confunden sus papeles; la regresión psicológica del segundo, aprisionado en un ámbito mental amniótico que literalmente lo arrastra a sumergirse y revolcarse en vísceras maternas, se reproduce en el primero cuando abandona la condición de espectador de un proceso judicial para adoptar la de prófugo de la justicia, a la que lógicamente lo empuja la patraña mediante la cual logra entrevistar al “Carnicero de Stonehill”. Esa especie de involución hacia lo asqueroso, abominable y fuera de la ley explica por qué el periodista, pese a los contratiempos, podrá llevar a cabo su misión de escribir. Julia Kristeva asevera que la abyección no dista demasiado de los impulsos creadores; en sus palabras, “sentimos lo abyecto si el Otro se instala en el espacio que debería ocupar nuestro Yo; pero ese Otro ha de darme ser” (Powers 10). El poder del horror, la invasión de lo que creemos que es nuestra identidad por algo ajeno y no dominable, el asedio al que la conciencia y su racionalismo son sometidos por el inconsciente y su temida oscuridad, propician el ansia de purificación tanto en los ritos religiosos como en los

\footnotetext{
\begin{tabular}{l} 
Revista Iberoamericana, Vol. LXXVI, Núms. 232-233 Julio-Diciembre 2010, 821-836 \\
\hline ISSN 0034-9631 (Impreso)
\end{tabular}
} 
“actos catárticos por excelencia que llamamos arte” (Kristeva, Powers 17). En efecto, sólo después de convertirse en forajido y aceptar que amar y asesinar no son acciones tan distintas, conseguirá el narrador de Barrera expresarse (200).

También el corazón es un descuido, con todo, nos reserva algo más que una trama que delata buenos conocimientos de lo humano. Creo que un atractivo adicional de la obra radica en su sorprendente manejo de lo metanarrativo. Entre otras historias, esta novela nos cuenta la de cómo ella misma acata su sino verbal, cómo la escritura comprende su naturaleza de artificio. Además de lo que ya he comentado acerca de los orígenes del impulso expresivo del narrador protagonista, conviene que reparemos en que incluso el lector virtual, a la larga, será absorbido por el mundo novelesco; ello sucede cuando quienes leen se percatan de que su acercamiento al texto se ha desarrollado paralelo al de Cecilia, la anhelada mujer del periodista, que se había quedado en Venezuela y a quien obsesivamente, temiendo que le fuese infiel, él ha recordado en su narración. A su lado, luego de regresar a Caracas como fugitivo, esperando la extradición y el juicio, el protagonista se encierra a concluir su relato:

Cuando termino una página, la imprimo, se la doy y ella lee [...]. Ahora estoy en la última página. Cecilia también lo intuye. Ella espera ver el punto final. No sé qué piensa. No sé qué siente. No sé cómo va a reaccionar. (199)

Lo anterior podría interpretarse de dos maneras: o la novela que hemos leído es una celebración de la comunión literaria, en la que escritura y lectura se vinculan eróticamente en una alegoría; o la literatura misma ha de equipararse con una irreversible inmersión en lo abyecto, sin esperanzas de una catarsis que nos devuelva la pureza: el narrador, para obtener el don de la palabra, ha de “asesinar" a su mujer, despojarla de su ser y entregar al lector un cuerpo ficticio, vacío, donde logre introducirse. La monstruosidad del "Carnicero de Stonehill” se duplicaría en la del escritor, que aniquila la supuesta verosimilitud de sus criaturas para que podamos incorporarlas como ficciones en nuestra realidad. Esa alternativa en la que arte y horror se dan la mano está sustentada por el sarcasmo del título También el corazón es un descuido, aparente cursilería a tono con los celos y el bolerismo que afectan a casi todos los personajes, pero que encierra, en el fondo, una alusión aterradora, muy concreta, a un olvido del Carnicero en medio de sus prácticas de anatomía (138). Dudo que cualquiera de esas opciones interpretativas sea descartable; luego de una historia tan desaforada, casi camp, sólo la aceptación de lecturas “abiertas” - ¿anatómicamente?- parece factible. Y semejante indeterminación, a mi modo de ver, prueba la destreza narrativa de Barrera.

Si su primera novela recreaba tanto los crímenes de un psicópata como las peripecias del periodista que se ve forzado a identificarse con él para escribir, aunque el tono y la anécdota sean distintos y el componente rocambolesco haya desaparecido, en su segunda novela, el autor lleva la estructura doble de su proyecto inicial a un nuevo

Revista Iberoamericana, Vol. LXXVI, Núms. 232-233 Julio-Diciembre 2010, 821-836 
grado de sofisticación que hace posible una reflexión sostenida sobre cómo interactúan lo privado y lo colectivo, los afectos y el lenguaje.

El argumento de La enfermedad, a primera vista, es tan sencillo y transparente como las dos palabras de su título y su para nada libresca escritura. El médico Andrés Miranda se entera de que Javier, su padre, morirá en poco tiempo de un cáncer que ha hecho metástasis cerebral; simultáneamente, uno de los pacientes de Andrés, Ernesto Durán, se empeña en que le diagnostiquen una enfermedad que la medicina tradicional no descubre. Esas dos historias, sólo tenuemente coordinadas, pronto se desarrollan en vertientes de gran autonomía, aunque de un modou otro todavía especulares: las reacciones del padre de Andrés ante la revelación de su mal, contradictorias y conmovedoras, y las de la secretaria de Andrés, Karina, ante la obsesión de Durán, a la que se entrega haciéndose pasar por su jefe en la correspondencia electrónica. Enfatiza la duplicidad anterior la división del libro en mitades que se indican con lapidarios numerales: I y II.

Los ecos que acabo de describir pronto quedan sobredeterminados en el sistema de las formas y los géneros narrativos, donde la alteridad abunda. Justo cuando la historia se suspende de la parte I a la II, notamos, por ejemplo, que los procedimientos hasta ahora "literarios" o estéticamente "elevados" se tiznan de hábitos provenientes de los medios de comunicación de masas -como el suspense de las series televisivas: "tienes cáncer, papá” concluye la primera parte (98) y, después del interludio y un párrafo retardador, volvemos a encontrarnos con el "tienes cáncer, papá" (101); lo mismo cabría decir de la técnica de alternar las dos tramas principales, característica del roman caballeresco y el sentimental después explotada por géneros tanto de la pulp fiction como del cine; habría de señalarse, además, que en un estrato más inmediato de la expresión el español de esta novela presenta similitudes con su conducta en lo que respecta a los géneros: su extraordinaria cotidianidad proviene no tanto de la asimilación del habla informal o coloquial del caraqueño de clase media, cosa que en efecto ocurre a lo largo de estas páginas, como de la aceptación manipulada con maestría de los tics léxicos del periodismo venezolano -"lucir" por "parecer"- o los anglicismos usuales en la prensa diaria pero no representativos del habla nacional - "tener sexo" por "tener relaciones sexuales". El entrecruzamiento de lo alto y lo bajo, lo culto y lo seudoculto, así pues, contribuye a fortalecer la bitonalidad de esta prosa.

¿Adónde nos conduce el laberinto de rigurosas duplicidades que diseña Barrera? El mayor de los logros de La enfermedad estriba en que el andamiaje previo suscita una lectura dispuesta a dar con un código "otro" -el referente de los acontecimientos novelados no se reduce a una anécdota factible o, sin más, realista, sino a otra narración, menos obvia, cuya captación se impone como desafío. Numerosas son las pistas que lo indican. Una de las más importantes la ofrece un pasaje crucial, donde el lector podría ver su propia identidad convergir con la de Andrés, enfrascado en tareas hermenéuticas tan poco desdeñables como la de entender su destino:

Revista Iberoamericana, Vol. LXXVI, Núms. 232-233 Julio-Diciembre 2010, $821-836$
ISSN 0034-9631 (Impreso) 
Leyendo El cuerpo herido, un diccionario imprescindible escrito por Cristóbal Pera, encontró por fin las palabras que tanto buscaba: “Según el lenguaje bélico, tan frecuentemente utilizado como metáfora global de la cirugía, la operación quirúrgica cruenta sería un acto de violencia, en el que se hace uso de la fuerza física para penetrar en el espacio anatómico del paciente, 'someter' al enemigo -la enfermedad concretada en la lesión-, desarmarlo y destruirlo”. [...] Incluso partiendo de que fuera una acción salvadora, [la vocación médica de Andrés] parecía estar siempre en otro lado [...]. "La violencia quirúrgica ha generado la imagen del poder del cirujano sobre el paciente y de la entrega de éste en un ritual de sumisión”, agrega Cristóbal Pera en su libro. Sin embargo, para Andrés, el poder se fraguaba en otro espacio, en el espacio del saber. (108-109)

En este momento, cuando las prácticas alegóricas se perfilan como posibilidad de lectura -y la alegoría no es otra cosa que una "metáfora global”3-, muchos elementos presentes en la historia empiezan a articularse como red de significados sociales. De poder, nada más y nada menos, está imbuida la medicina según los discursos que se rememoran; no cuesta homologar entonces el plano individual con el político: tal como el padre del protagonista está enfermo y los diagnósticos son poco esperanzadores, la patria podría estar grave: “Javier Miranda [habita] una estructura dañada, metido dentro de una piel que no gobierna, que ya no dialoga con él, que tiene otro gobierno, que no le responde" (106); y tal como Ernesto Durán anhela irracionalmente una cura para una dolencia que parece más bien metafísica, las relaciones políticas degeneran en la lamentable tragedia de un pueblo receptivo a los engaños mesiánicos:

Andrés recuerda ahora esa anécdota. Estaban en plena campaña electoral. De regreso a casa, escuchó unas propagandas políticas en la radio. Había llegado la hora de los pobres, gritaba el candidato de turno, mientras arengaba en contra de los viejos partidos políticos y prometía un nuevo paraíso. (59-60)

Lo cierto es que en La enfermedad lo personal y lo nacional no se disocian:

Andrés de repente piensa en que la situación política ha salvado a muchos matrimonios que ya no tenían de qué hablar. Ahora las familias se reúnen y ya tienen tema. La política ha resucitado sus vínculos, sus euforias, sus maneras de distribuir las pasiones. (90)

El pathos -es decir, la enfermedad y el horizonte afectivo- que evoca Barrera conmueve porque enlaza las experiencias fundamentales de muchos individuos en la Venezuela de fines del siglo xx y principios del xxi. Notar que las dualidades que traspasan la totalidad de la novela podrían corresponderse con las patentes en el país

3 Sobre la definición de la alegoría como tropo amplificado véase Curtius (1: 73) y Murphy (238).

(IS) $\frac{\text { Revista Iberoamericana, Vol. LXXVI, Núms. 232-233 Julio-Diciembre 2010, 821-836 }}{\text { ISSN 0034-9631 (Impreso) }}$ 
añadiría otra razón para aseverar que estamos ante un retrato de la desazón que produce la supervivencia de rancias afecciones de la nación: el autoritarismo fundado en el ahondamiento estratégico de las divisiones de clase y los obstáculos que detienen los intentos de diálogo entre las partes afectadas - una de las subtramas, de hecho, incluye un "pacto” entre el agónico Javier Miranda y su criada (125).

Dicho retrato, no obstante, es inteligente, jamás recae en la bastedad de los discursos que dominan la escena política actual. El humor, para no ir muy lejos, impide que la críptica radiografía del país se convierta en sermón bellista o bolivariano, letrado o heroico. La distancia que la ironía del narrador introduce en la enunciación contribuyen también a que los exegetas con tendencias aleccionadoras no logren atenerse a interpretaciones cómodas o reductoras. Después de todo, el Kitsch de los medios de comunicación de masas ha anunciado su presencia y, con él, hemos de reparar en un grado insoslayable de indeterminación, que aconseja vacilar entre lo literal y lo figurado, lo serio y lo burlesco. En algunas ocasiones, socarronamente, el narrador señala ese abismo tendido ante nosotros:

"El tifus es menos contagioso que la histeria”, escribió Joseph Roth. Adelaida [una secretaria amiga de Karina] no lo sabe, jamás ha leído y jamás leerá a Joseph Roth, pero piensa más o menos lo mismo. (130)

La voz que forja este universo lleno de personajes verosímiles está al tanto de su oficio y los precarios orígenes de las verdades construidas con palabras -la realidad contenida en una obra literaria no es la de las vivencias aunque pueda a veces coincidir con ella. La advertencia de La enfermedad se ciñe a una discreción ejemplar: adopten la apariencia de una novela o la mucho más peligrosa de una promesa de cura y redención, las fronteras entre lenguaje e ilusión son siempre indiscernibles. La interpretación debe prolongarse hasta que la posición del lector y la de Andrés acaben confundiéndose:

A las siete de la noche baja de la montaña [el Ávila]. No hay nadie más en el carro que desciende por el teleférico. Siente que la suerte le ha regalado un raro privilegio. El viaje hacia la ciudad ofrece un paisaje extraordinario. Las líneas iluminadas de las autopistas, las luces de las urbanizaciones y de los barrios, todo traza sobre la penumbra otro mapa, una ciudad diferente, casi irreal; un paisaje detenido, sin movimiento, una Caracas inventada en ese instante, que de seguro desaparecería cuando apenas él entrara de nuevo en ella. Suspendido en el aire, casi colgado sobre ese precipicio lejano que es ahora la ciudad, toma entonces la decisión, marca el número [en] su teléfono celular. (70)

La suspensión que precede al cumplimiento de un deber moral -anunciarle un cáncer a su padre- se produce tras la contemplación de un espacio tocado, a la vez, por la modernidad y la noche.

Revista Iberoamericana, Vol. LXXVI, Núms. 232-233 Julio-Diciembre 2010, $821-836$
ISSN 2154-4794 (Electrónico) 
NOCTURAMA

Laprestigiosa y extensa labor deAna Teresa Torres vuelven significativa su aportación al ciclo del chavismo. En novelas previas como El exilio del tiempo (1990) y Doña Inés contra el olvido (1992), Torres se había adentrado en el terreno de lo "intrahistórico" (Rivas; Cunha), arriesgándose a situar sus fábulas historiográficas -es decir, sobre cómo se decide cuáles son las versiones "correctas" del pasado- en una encrucijada tan imprevista como la de la sátira menipea y la fantaciencia que encontramos en Malena de cinco mundos (1997). Con Nocturama, sin embargo, el país que retrata parece el de experiencias inmediatas; su historicidad no es la de la reflexión sobre el pasado, sino la de un testimonio que rescata para lectores venideros un presente a punto de ser borrado o prohibido.

Definir como testimonial el acontecer de una ciudad casi onírica, de localización vaporosa, con un protagonista que no está seguro de cómo se llama y acepta el nombre de Ulises Zero -tan literario o a propósito artificioso como el de los demás personajes (Eudora Welty, Wakefield, Mary Shelley, Aspern, etcétera)- y hasta con un narrador resbaladizo y nada confiable -pues se perfila como un haz de voces-, podría parecer a primera vista un sinsentido, pero pronto la lógica narrativa lo exige. Ello ocurre, al menos, en el orbe pragmático en que los primeros lectores reciben la supuesta "ficción". Torres ha divulgado su opinión personal sobre la situación venezolana en ensayos, entrevistas y charlas numerosos; varios rasgos que resalta en el país se emparientan con los del enigmático escenario de su novela. Ante todo, por el deterioro social y la miseria:

[Ulises] llegó a una calle que se encontraba en un estado maloliente, con las entradas de los edificios tapadas por sacos de basura, y atravesada por ratas despavoridas. (42) Esta librería fue la más famosa de la ciudad y ahora nadie se atreve a venir [...] a los pocos clientes no queremos que los atraquen. (43)

Alrededor de la fila de vehículos detenidos aparecieron muchas personas que vendían agua, galletas y otros comestibles [...] Ulises se asomó al vacío y pudo observar que en la parte interior, es decir, debajo del puente, se acumulaban viviendas construidas con ladrillos en algunos casos, con planchas de metal en otros, e incluso algunas de ellas parecían, a la distancia, estar fabricadas con cartones. (139)

Igualmente, la conducta de un gobierno gesticulador y teatral, la violencia, la agitación general de "Nocturama" se asemejan a las de Caracas, con sus tomas de edificios en nombre del "poder del pueblo" (162), marchas, protestas (175) y asesinatos a sangre fría de miembros de la oposición que las autoridades -militares, por cierto-se esfuerzan en soslayar (184). El dato definitivo es el delirio heroico que se apodera de la política y la vida pública de "Nocturama", donde paranoia y divisiones se profundizan, tal como en la "República Bolivariana":

Revista Iberoamericana, Vol. LXXVI, Núms. 232-233 Julio-Diciembre 2010, 821-836 
El espionaje, hasta entonces desconocido entre ellos, comenzó a hacer estragos. Todos se vigilaban unos a otros [...] A veces el héroe los esperaba para ejercer la oratoria durante horas [...] Propusieron pedirle que llegaran a un acuerdo en cuanto a las noches de oratoria, pero tampoco fue posible. (76-77)

Moriremos de hambre pero nuestra historia será ejemplo de los pueblos. Esta opinión [de los seguidores del héroe] no era totalmente compartida por los nocturanos. Grupos facciosos comenzaron a repartir propaganda clandestina: [...] "Mi héroe por una coliflor”. (78)

Una vez establecido el paralelo entre "Nocturama” y Caracas o Venezuela la dimensión alegórica de la novela se hace patente y, por ello, algunos lectores se han referido a "un testamento literario de estos años recientes" (Linares B-5). Con el magma sombrío de su ciudad de aspecto catastrófico; con su protagonista de identidad ambigua que busca a un tal Díaz-Grey para que le dé la clave del misterio de su origen -Díaz-Grey se confunde, a su vez, con muchas personas-; y con su narrador singular y plural entregado a un discurso indirecto proliferante, de enunciados ajenos que se contienen unos a otros como en una caja china, la alegoría reformula al país real en términos que no le son ajenos a la psicología. Erich Neumann, por ejemplo, describió formas "ourobóricas” de regresión del Ego hacia el inconsciente registradas en remotas tradiciones con el símbolo de la serpiente que se muerde la cola, lo cual sugería la "indiferenciación total donde todo sale de todo y de nuevo se reincorpora en todo" y, también, el "incesto" psíquico del sujeto que se sumerge en los ámbitos preconscientes de lo materno (266). Testigo de horrendos totalitarismos de la primera mitad del siglo xx, Neumann no olvidaba que la psicología tiene vertientes sociales:

Cuanto más inconsciente e inmadura permanece la personalidad [del individuo], cuanto más germinal el Ego, más [inadvertida y ourobóricamente] se proyectará en el grupo su experiencia de la Psique. (286)

No obstante, el caos “nocturno” de esta novela no anula la capacidad de intervención o, para decirlo sin rodeos, la esperanza que le quede al lector. El clima apocalíptico del desenlace -hasta la "Gran Montaña" (¿el Ávila?) en cuyo seno se recoge la ciudad se abre "en medio de llamas" (196)- no basta para agotar las posibilidades de continuidad de la trama. Ulises y la mujer que al final lo acompaña de alguna manera se las arreglan para seguir con sus vidas, cambiando de identidad o asimilándose a la imaginación todopoderosa del narrador. Varios psicólogos, en efecto, han señalado que las regresiones no tienen que ser negativas, e incluso han de considerarse indispensables en el proceso de individuación (Jung 8: párr. 67-68). La indeterminación de Nocturama, así pues, apunta a cierta ética de la supervivencia.

Revista Iberoamericana, Vol. LXXVI, Núms. 232-233 Julio-Diciembre 2010, 821-836
ISSN 2154-4794 (Electrónico) 
La plasticidad del futuro a la que Torres parece inclinarse se reproduce en la organización formal de la narración, que oscila enriquecedoramente entre los guiños a lo detectivesco y a la ciencia ficción —los experimentos de "adjudicación aleatoria de identidades” realizados por Díaz-Grey tal vez propiciaron la amnesia de Ulises. Dicha plasticidad halla un correlato, asimismo, en el repertorio de interpretaciones legítimas otorgables al texto. La hipotética iniciativa de plasmar una Caracas atrapada en la vorágine ourobórica de la violencia y el neocaudillismo se explicaría, entre otras cosas, por los impulsos "semióticos" del arte que Kristeva ve como "revolucionario", aquel que transgrede la restrictiva claridad y el racionalismo patriarcales que Jacques Lacan atribuía al orbe de "lo simbólico" (Révolution passim). Sin revivir en el lenguaje el vértigo proteico de lo indiferenciado y oscuro -casi al pie de la letra una "noche" como la de Cupolo-, una literatura responsable tampoco sería capaz de adquirir el instrumental expresivo que las situaciones de crisis exigen. El pathos y la intensidad que Nocturama comparte con la mayoría de las obras del ciclo del chavismo intenta, ni más ni menos, darle al sentimiento trágico de muchos venezolanos de hoy un alentador giro de tuerca.

Creo que repasar reflexiones explícitas de Ana Teresa Torres como ensayista respaldaría los planteamientos previos:

\begin{abstract}
El país se ha visto zarandeado por un trauma que [...] ha constituido la más dura etapa de nuestra historia reciente; sería extraño que no reapareciera en la escritura. [Algunos ya empiezan a demandar la novela de Chávez.] Constato que en estos años he leído más acerca del totalitarismo que en casi toda mi vida anterior. [He comprendido] en esta edad tardía que lo totalitario consiste en obligar al ciudadano a diluirse en el pueblo, para que luego, en nombre del pueblo, pueda hacerse cualquier cosa contra el ciudadano. Esta experiencia mía (nuestra) quedará para la literatura. (“Cuando la literatura” 922-923)
\end{abstract}

Las constantes "diluciones” son lo más pesadillesco que depara Nocturama. Enfrentarse a ellas tal vez equivalga a una manera de no perder la lucidez y, aun, de cultivarla en el aquí y ahora de la nación.

\title{
LATIDOS DE CARACAS
}

Desde fines de la década de 1980, el desmantelamiento del gran relato de una Venezuela destinada al desarrollo ha tenido en la literatura un par de efectos visibles. Uno ha sido la adopción de posturas más exigentes ante el lenguaje; sobre todo, ante su capacidad de ocultar la índole convencional de sus imágenes de lo real. El otro consiste en el redescubrimiento de la introspección, no como refugio para un sujeto que escapa del desencanto del mundo exterior, sino como mirador crítico de los materiales anímicos con los que el fracaso puede asimilarse. La obra de Gisela Kozak, desde Pecados de la capital, con sus penetrantes análisis narrativos de la identidad sexual y los vínculos entre

Revista Iberoamericana, Vol. LXXVI, Núms. 232-233 Julio-Diciembre 2010, 821-836 
el individuo y un entorno saturado de discursos, encaja en ese sistema de inquietudes.

Latidos de Caracas, su única novela por ahora, claramente recurre a una trama donde los mecanismos metafóricos, es decir, homologadores de dos o más campos semánticos en principio independientes, orientan la ficción hacia cuestionamientos específicos de la crisis nacional. El título constituye un indicio por la polisemia que instaura en los umbrales del texto. Si por una parte la somatización de la ciudad nos apresta para lecturas donde los individuos y los dominios sociales se hacen equivalentes o se reflejan, por otra, el encuentro entre personajes parece provisto tanto de urgencia y sincero deseo -la ciudad puede servir de escenario para una comunión-como de irónicos enjuiciamientos y amargo escepticismo -dichas comuniones podrían estar asediadas por la vacuidad de los clichés: evocar el "corazón” de la ciudad es un arma elocutiva de doble filo.

Cuerpo y urbe se identifican en nuestra lectura siempre que no se excluyan de lo corporal los factores psicológicos que lo hacen un espacio primordial por el que transitamos hacia lo "otro". Sarracena, la protagonista, es arquitecta y más o menos consciente de las múltiples maneras como se comunica el individuo con sus alrededores, sean estos ámbitos privados o compartidos. Sus clases o sus reflexiones filotópicas ocupan muchos renglones de la novela. Lo esencial, no obstante, es que Sarracena se precipita en una relación con un hombre más joven, Andrés, que suscita conflictos tanto con los parientes de él como con las expectativas de felicidad personal y vida conyugal "perfecta" absorbidas por ella, aunque renuentemente, a lo largo de su vida; y ese gran colapso a punto de producirse-Kozak evita revelar el desenlace- se vislumbra en el país donde la protagonista se siente atrapada. En algún pasaje, el desplazamiento metafórico de significados desde un polo de introversión a uno de extraversión es tan evidente que, incluso con cierto rigor cinematográfico -Sarracena no solo recibe un nombre felliniano, sino que es "fanática del cine"-, se materializa en un puente gracias al cual el interior mental accede al exterior urbano:

Nada llega a feliz término, todos roban, y ella gana quinientos dólares al mes, vive arrimada en un cuarto, no tiene donde caerse muerta: para esto le ha servido su título de arquitecta. [M]il veces mierda en este país maldito, con su crisis interminable, sus ricos y sus millones de pobres, su delincuencia inmunda, la película de deterioro que lo cubre todo... Y pensar que se había quedado en Venezuela por el perro de Marcos [su ex marido]... Sarracena tiembla levemente: hasta la aventura con Andrés le sale mal [...]. Qué hace ella detrás de un pendejo de diecinueve años velándole una cita, piensa mientras pasa por el puente que une la Universidad con la Plaza Venezuela[...] Los automovilistas tocan y tocan corneta. Un hombre le grita mamita rica y otro que le va a mamar la cuca. Sarracena [...] siente asco al ver la boca desdentada de un mendigo. (59)

Latidos de Caracas, desde ese punto de vista, se afilia a una antigua narrativa latinoamericana aptamente estudiada por Doris Sommer: la de las historias de amor en

\footnotetext{
\begin{tabular}{l} 
Revista Iberoamericana, Vol. LXXVI, Núms. 232-233 Julio-Diciembre 2010, 821-836 \\
\hline ISSN 0034-9631 (Impreso)
\end{tabular}
} 
que se organiza un ideario sobre la nación. El disonante romance, de hecho, recuerda demasiado las ilusiones que se hizo el país en decenios de aparente prosperidad:

[Andrés] le entrega a Sarracena un estuche con dos botellas de Etiqueta Negra que le trajo de Margarita y recibe a cambio besos y cosquillas.

-Vámonos al hotel Torremolinos.

-Está bien y gracias por este regalo que me recuerda al primer gobierno de Carlos Andrés Pérez. Mi madre siempre dice de esa época: “Ay mijita, éramos felices y no lo sabíamos”. (99)

La diferencia decisiva con respecto al pasado literario es que Kozak sitúa la imaginería nacional sobre el abismo de una modernidad ya frustrada -de allí la Caracas automotriz de la que emergen, para Sarracena, náusea y vapores de auténtico albañal humano.

La otra gran fuente de ambivalencia en la novela se halla en la cualidad dual del maltrecho idilio de Sarracena y Andrés. Aunque nunca podremos descartar del todo la posibilidad de un final feliz, la narración está minada de indicios que se oponen a la ingenuidad. "Hija”, le dice la madre, “espero que algún día me des un nieto”, y Sarracena "suspira”, imaginándose a ella y Andrés “con un cochecito y un sonrosado bebé” (110). La ironía crea una considerable escisión entre los eventos, apenas esbozados, y el lugar de enunciación que socava la candidez tanto de los personajes como del lector: "basta de romances sin riesgo que casi no merecen contarse, basta de desechos de frases y de lugares comunes”, oímos decir casi al final, no sabemos si al narrador terciopersonal o a Sarracena misma, puesto que el discurso indirecto libre nos coloca en un lindero impreciso (115). El desenlace, entre el expresionismo y la cursilería de la publicidad o la telenovela, con un galán salvador transformado en paladín de la razón ante una Caracas -y una heroína- al borde de la locura, confirma que la actitud narrativa no se define -lo cual, por cierto, nos ofrece, en absoluta libertad hermenéutica, la oportunidad de entrever soluciones dichosas o desdichadas a la anécdota: el lugar común, no lo olvidemos, se integra en una retórica y el practicante de ésta necesita cierta distancia para entender la índole combinatoria de su código. El amor acaba convertido en un elemento más en un sistema de convenciones que pueden, no obstante, darnos la medida de lo que llamamos realidad: nuestra identidad psíquica se funda cuando nos compenetramos con la conducta de los signos, aun los trillados.

La zozobra de Sarracena, atenuada por el ejercicio de cordura que se espera del enfrentamiento con una obra "abierta" -en la acepción de Umberto Eco-, acaba, sin embargo, contagiando, en un orbe pragmático, al lector, en particular si éste comparte las experiencias caraqueñas de la protagonista. Una metáfora que infringe el contrato de lectura de la ficción se agrega, así, a las que he señalado hasta ahora -es decir, la de psique y ciudad, la de idilio y nación, la de amor y retórica-: la ciudad novelada puede ser la ciudad vivida; la narración aspira a funcionar como testimonio. La Caracas que

Revista Iberoamericana, Vol. LXXVI, Núms. 232-233 Julio-Diciembre 2010, 821-836 
Kozak retrata con aspereza haciendo que su Sarracena vea el mundo "como una bola de mierda” (46), o que Parque Central esté atacado “por una epidemia de lepra” y que en él flote “una atmósfera de pobreza y podredumbre”(14), con aires, además, “emponzoñados” por los "tufos” del Guaire -río cloaca- (114), es la arena incómoda donde luchan las esperanzas y los desengaños entre los que se han debatido muchos venezolanos tras la puesta en evidencia del desarrollismo y el desmoronamiento del nuevorriquismo de los años setenta y los tempranos ochenta, tan parecido a la "felicidad” hoy en día, pero tan culpable, también, de las ruinas por las que en estos momentos tienen que aprender a andar los supervivientes si quieren que, en efecto, no sean letales la "lepra” o la "enfermedad" que los narradores actuales divisan. El final abierto de Latidos de Caracas, creo, es una oportuna invitación no sólo a la imaginación participativa, sino a una participación imaginativa en las formas del presente, sin importar lo duras que sean. FÁBULAS DEL DETERIORO

A lo largo de este trabajo he empleado el adjetivo “expresionista” para describir un elemento constante en todas las novelas analizadas. La palabra sin duda apunta al legado histórico de las vanguardias germánicas, pero tal referente es remoto en el caso venezolano actual. La raíz directa del fenómeno la encontraremos, más bien, en un influyente narrador de la tradición nacional que Barrera, Torres y Kozak sin duda conocen, Salvador Garmendia, cuyas obras de fines de los cincuenta y de los sesenta y setenta fueron por su difusión, calidad y continuidad lo más cercano que se produjo en Venezuela al "Boom” hispanoamericano. Si se examinan pasajes del libro que Ángel Rama dedicó a Garmendia, se notará de inmediato que el vocabulario se adecúa a las novelas del ciclo del chavismo:

\begin{abstract}
Un universo visceral poblado de malos olores, malos sabores, deformidades. Los hombres y mujeres que pasan por sus novelas parecen descendidos de una galería pictórica expresionista [...]. Garmendia consigue que los seres humanos normales y hasta rutinarios asuman aspectos insólitos, apariencias sobrecogedoras[,] muchas veces repugnantes como los monstruos de circo [...] Son aspectos de una técnica narrativa expresionista [...] Todo pertenece a la realidad pero ella es alucinante, atroz, dolorosa; a veces perversa. Ninguna confianza puede depositarse en sus formas, ya que no son otra cosa que manifestaciones protoplasmáticas de una materia intestinal, en constante transformación y decaimiento. (23-26)
\end{abstract}

Lo más curioso de la actualización de ese legado por parte de Barrera, Torres y Kozak es que insinúa que nada ha cambiado demasiado y los escombros, el deterioro que Garmendia percibía en plena era de derroche petrolero -la popularmente llamada "Venezuela saudita" de los sesenta y setenta-siguen siendo los de hoy, cuando oficialmente se asevera el triunfo de nuevos valores -los de la "Quinta República", la "Revolución

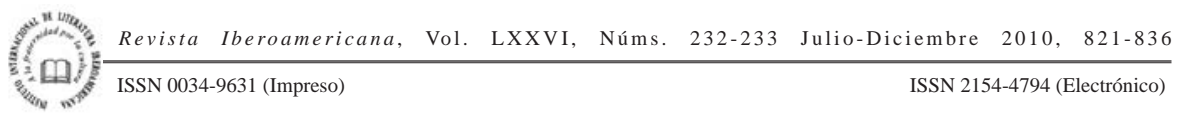


Bolivariana”, la Venezuela que "ahora es de todos”, para sólo recordar las fórmulas y los slogans estatales.

Además de una abyección exasperada que sirve tanto para representar un mundo como para codificar metanarrativamente la pertenencia a una estirpe literaria, los novelistas del ciclo del chavismo comparten otra tradición filtrada por Garmendia: todos eligen la topografía moderna de Caracas. ${ }^{4}$ Pero al combinarse el escenario urbano con el neoexpresionismo al que aludía Rama, el espacio parece condenado a encarnar el malestar anímico o físico de los personajes, y tiende a convertirse, por tanto, en ámbito de amenazas, delirio, inquietud generalizada. Desde los años de vigencia del naturalismo y el modernismo -con figuras como Manuel Díaz Rodríguez, Rufino Blanco Fombona o Miguel Eduardo Pardo- pueden rastrearse antecedentes venezolanos de una narrativa urbana asfixiante, angustiada (Gomes 217-219), así que sería legítimo sostener que ocurre otra alianza entre la historia literaria y los autores del presente, que acuden a ella para estructurar vivencias difíciles de articular en términos inéditos.

Un tercer factor común a las obras de Barrera, Torres y Kozak es la desconfianza ante la retórica mesiánica, heroica, didáctica que domina la vida pública. Aunque sin duda la descripción que hacen sus obras de los efectos del chavismo o las condiciones que lo crean lejos está de ser halagadora para éste, tampoco puede argumentarse que se adhieren a la vehemente polarización política venezolana de fines del siglo xx y principios del xxi. La indeterminación de sus tramas y con frecuencia de su lenguaje, la imposibilidad de delinear con claridad la verdad rotunda o, como diría Eco, el "univocalismo" que se oculta tras sus alegorías (6), esboza, tal vez, un deseo adonde se encaminan las estructuras afectivas captadas por estas narraciones: la de un proyecto nacional que se traduzca antes en diálogo o matizada búsqueda de sentido que en maniqueísmo, división y contienda.

\section{BiBLIOGRAFÍA}

Barrera Linares, Luis. "Palabras en guerra: enfrentamientos discursivos de principios de siglo”. C. Pacheco et al. Nación y literatura. 873-888.

Barrera Tyszka, Alberto. La enfermedad. Barcelona: Anagrama, 2006. También el corazón es un descuido. México: Plaza \& Janés, 2001.

Bronfen, Elisabeth. Over Her Dead Body. New York: Routledge, 1992.

Campos, Miguel Ángel. Desagravio del mal. Caracas: Fundación Bigott, 2005.

Carrera Damas, Germán. El bolivarismo-militarismo. Caracas: Ala de Cuervo, 2005.

4 También el corazón es un descuido no es una excepción: la capital venezolana es el punto de origen y retorno del protagonista.

Revista Iberoamericana, Vol. LXXVI, Núms. 232-233 Julio-Diciembre 2010, 821-836 
Coronil, Fernando. The Magical State: Nature, Money and Modernity in Venezuela. Chicago \& London: The U of Chicago P, 1997.

Cunha, Gloria da. Mujer e historia: la narrativa de Ana Teresa Torres. El Tigre: Centro de Actividades Literarias El Tigre, 1994.

Cupolo, Marco. Petróleo y política en México y Venezuela. Caracas: Equinoccio, 1996.

Curtius, Ernst R. Literatura europea y Edad Media latina. M. Frenk y A. Alatorre, trads. 2 vols. México: FCE, 1981.

Eco, Umberto. The Open Work. A. Cancogni, trad. Cambridge: Harvard UP, 1989.

Gomes, Miguel "El lenguaje de las destrucciones: Caracas y la novela urbana”. Inti 37-38 (1993): 217-224.

Kozak, Gisela. Latidos de Caracas. Caracas: Alfaguara, 2007.

Kristeva, Julia. La Révolution du langage poétique. Paris: Seuil, 1974. Powers of Horror. L. Roudiez, tr. New York: Columbia, 1982.

Jung, Carl G. Collected Works, C. F. R. Hull et al. trad. Princeton: Princeton UP, 1953-1977.

Linares, Albinson. "Caracas representa el caos en que estamos perdidos. Entrevista a Ana Teresa Torres”. El Nacional (Caracas, 27/11/06): B-15.

McBeth, Brian. Juan Vicente Gómez and the Oil Companies in Venezuela, 1908-1935. Cambridge: Cambridge UP, 1983.

Murphy, James. Rhetoric in the Middle Ages. Berkeley: U of California P, 1990.

Neumann, Erich. The Origins and History of Consciousness. R. F. C. Hull trad. Princeton: Princeton UP, 1995.

Pacheco, Carlos, Luis Barrera Linares y Beatriz González Stephan, eds. Nación y literatura. Caracas: Fundación Bigott / Equinoccio, 2006.

Poe, Edgar A. "The Philosophy of Composition". Literary Theory and Criticism. L. Cassuto, ed. Mineola, New York: Dover, 1999.

Rama, Ángel. Salvador Garmendia y la narrativa informalista. Caracas: UCV, 1975.

Rivas, Luz Marina. La novela intrahistórica. Valencia: Universidad de Carabobo, 2000.

Sommer, Doris. Foundational Fictions. Berkeley: University of California, 1991.

Torres, Ana Teresa. “Cuando la literatura venezolana entró en el siglo XXI”. C. Pacheco et al. Nación y literatura. 911-923. Nocturama. Caracas: Alfa, 2006.

Williams, Raymond. Marxism and Literature. Oxford: Oxford UP, 1977. 